\title{
Alteromonas rubra sp. nov., a New Marine Antibiotic-Producing Bacterium
}

\author{
M. J. GAUTHIER \\ Centre d'Etudes et de Recherches de Biologie et d'Océanographie Medicale-I.N.S.E.R.M. Unité, 40, 06300, \\ Nice, France
}

Three strains of marine bacteria that produce a polyanionic antibiotic substance and a red pigment similar to prodigiosin have been investigated from morphological, physiological, and biochemical standpoints. Their phenotypic characters, together with the low guanine plus cytosine contents of their deoxyribonucleic acids, place these strains in the genus Alteromonas Baumann et al. The main features of these strains are sufficiently consistent and different from those of the alteromonads previously described to justify placing them in a new species, for which the name Alteromonas rubra is proposed. The type strain is strain no. 18 (=NCMB 1890).

Among the many marine bacteria that produce antibiotic substances on the usual culture media, a group of gram-negative bacteria was described (8) whose major genotypic and phenotypic characters resemble those of members of the genus Alteromonas Baumann et al. (2). Of these, those that produced violet-pigmented (violacein) colonies on seawater media were placed in a new species, Alteromonas luteoviolaceus (6).

The purpose of this study was to determine the taxonomic position of three strains of redpigmented alteromonads chosen from numerous similar strains isolated from the Mediterranean waters off Nice. These bacteria produce and release into their culture medium a polyanionic antibiotic which modifies bacterial respiration (7).

\section{MATERIALS AND METHODS}

Source of strains examined. The three strains examined were isolated from the Mediterranean Sea near Nice. The isolation medium used was marine agar (MA) (Difco). The strains were selected on the basis of the red pigmentation of their colonies and on their antibiotic activities against test bacteria. The three strains were placed in the Centre d'Etudes et de Recherches de Biologie et d'Oceanographie Médicale (CERBOM) collection under the numbers 18, 173 , and 198. Strain 18 was deposited in the National Collection of Marine Bacteria (Torry Research Station, Aberdeen, Scotland) as NCMB 1890. The type strain of Altermonas macleodii, strain 107, was included in this study as a reference strain.

Phenotypic analysis. Aside from the methods described below, the methods and the compositions of the media used have been extensively described in previous reports $(6,8)$. Unless stated otherwise, all cultures were grown on MA or in marine broth (MB) (Difco) and were incubated at $23^{\circ} \mathrm{C}$.
Electron microscopy. The cells were grown on MB for $18 \mathrm{~h}$, fixed on collodion, and then shadowed with platinum-palladium (4:1) under vacuum in a Balzers BAF 300 apparatus. Observations and photographs were made with an electron microscope (Hitachi type HU 12) at the Service de Microscopie Electronique de l'Institut Pasteur (Lille, France).

Production and analysis of pigments. Production of a red pigment was determined on MA with and without the addition of soluble starch $(5 \%$, wt/vol), on nutrient agar (NA) (Difco), and on Trypticase soy agar (BD-Mérieux, Marcy l'Etoile, France); all media contained $2.5 \%$ (wt/vol) sodium chloride. Pigments were extracted with ethanol or chloroformmethanol (1:1) from cells scraped off of solid media after 4 days of incubation. The absorption spectra of these extracts were determined by using a spectrophotometer Unicam SP800. A comparison was made with the pigments of Serratia marcescens A 170 (Institut Pasteur) grown on NA with added starch (5\%, $\mathrm{wt} / \mathrm{vol}$ ) and extracted by the same procedures described above. The chloroform-methanol extracts were fractionated by liquid chromatography with a high-pressure liquid chromatograph (Waters Associates, type ALC-GPC 244; elution by acetonitriletetrahydrofuran-water [4:1:5] in a MicroBondapak C18 packed column [4 $\mathrm{mm}$ ID by $30 \mathrm{~cm}$ ]; detection $546 \mathrm{~nm}$.

Growth at different salinities and determination of sodium requirements. The influence of salinity upon growth was investigated by adding artifical seawater (9) at various concentrations $(0,7,10,15$, $25,35,50,70,85$, and $112 \%$ ) to peptone (Difco) $(5 \mathrm{~g} /$ liter), yeast extract $(1 \mathrm{~g} / \mathrm{liter})$, and $\mathrm{PO}_{4} \mathrm{Fe}(0.1 \mathrm{~g} /$ liter) at $\mathrm{pH}$ 7.8. Sodium requirements were determined by a procedure described previously $(6,8)$.

Utilization of organic compounds. The following substrates were tested for utilization: acetate, pyruvate, DL-lactate, $\alpha$-ketoglutarate, succinate, fumarate, malate, citrate, $\mathrm{D}$-tartrate, malonate, gluconate, D-glucose, D-mannose, D-xylose, D-galactose, Darabinose, L-rhamnose, D-fructose, trehalose, mal- 
tose, cellobiose, raffinose, saccharose, lactose, starch, glycerol, erythrtol, sorbitol, inositol, adonitol, mannitol, dulcitol, salicin, and ortho-hydroxybenzoate. The utilization of these compounds as sole sources of carbon and the hydrolysis of chitin were determined by the techniques of Baumann et al. (1, 2), using BM Casamino Acids medium.

PHB accumulation. Synthesis of poly- $\beta$-hydroxybutyrate (PHB) was investigated in PHB artificial seawater medium by the method of Baumann et al. $(1,2)$.

Enzyme production. The synthesis of urease, ornithine, and lysine decarboxylases, arginine dihydrolase, and lecithinase was evidenced using the procedures described by Brisou (3). A microtechnique (API ZYM, API System, La Balme-lesGrottes, France) was used for the detection of several enzymatic activities using the following synthetic substrates (corresponding enzymes in parentheses): 2-naphthyl phosphate (pH 8.5 and 5.4) (alkaline and acid phosphatases), 2-naphthyl butyrate (esterase), 2-naphthyl caprylate (esterase lipase), 2naphthyl myristate (lipase), L-leucyl 2-naphthylamide (leucine aminopeptidase), L-valyl 2-naphthylamide (valine aminopeptidase), L-cystyl 2-naphthylamide (cystine aminopeptidase), $N$-benzoyl DL-arginine 2-naphthylamide (trypsin or related enzymes), $N$-benzoyl DL-phenylalanine 2-naphthylamide (chymotrypsin or related enzymes), naphthol AS BI phosphodiamide (phosphoamidase), 6Br-2-naphthyl $\alpha$-Dgalactopyranoside ( $\alpha$-galactosidase), 2-naphthyl $\beta$-D-galactopyranoside ( $\beta$-galactosidase), naphthol AS BI $\beta$-D-glucuronic acid ( $\beta$-glucuronidase), 2 naphthyl $\alpha$-D-glucopyranoside ( $\alpha$-glucosidase), 6 -Br2 -naphthyl $\beta$-D-glucopyranoside $(\beta$-glucosidase), 1 -naphthyl $N$-acetyl $\beta$-D-glucosaminide $(\beta$-glucosaminidase), 6-Br-2-naphthyl $\alpha$-D-mannopyranoside) ( $\alpha$-mannosidase), 2-naphthyl $\alpha$-L-fucopyranoside ( $\alpha$ fucosidase). Each substrate (50 nmol each) was dissolved in $0.1 \mathrm{ml}$ of a dense suspension of each bacterium. A reading was made after incubating the suspension for 1 to 3 days at $23^{\circ} \mathrm{C}$ by adding 1 drop of the following reagent: tris(hydroxymethyl)aminomethane $(2.5 \mathrm{~g}), 37 \% \mathrm{HCl}(1.1 \mathrm{ml})$, lauryl sulfate $(1 \mathrm{~g})$, distilled water $(10 \mathrm{ml})$, and Fast Blue BB (Sigma FO 250) (35 mg), $\mathrm{pH} 7.8$. A positive reaction resulted in a blue, violet, or orange color, depending on the substrate. The type strain of Alteromonoas maceodii, strain 107, served as the reference.

Antibiotic synthesis. Antibiotic synthesis was evaluated using several media (MA, blood MA, NA containing salt, and TSA) at various temperatures (on MA: $10,20,30$, and $37^{\circ} \mathrm{C}$ ). Measurement of antibiotic activity was made by direct deposition of a small amount of cell paste scraped off of solid media onto the surface of TSA ( $\mathrm{pH} \mathrm{6)}$ sown with Staphylococcus epidermidis (Institut Pasteur strain 53 124).

Susceptibility to inhibitors. The antibiogram method (4) was used for the determination of susceptibility to the following antibiotics (Sensi-discs, BDMérieux, France): colistin $(10 \mu \mathrm{g})$, polymyxin (300 $\mathrm{U})$, vancomycin $(30 \mu \mathrm{g})$, rifamycin $(30 \mu \mathrm{g})$, erythromycin $(15 \mu \mathrm{g})$, chloramphenicol $(30 \mu \mathrm{g})$, thiophenicol $(30 \mu \mathrm{g})$, novobiocin $(30 \mu \mathrm{g})$, oleandomycin (15 $\mu \mathrm{g})$, staphylomycin $(15 \mu \mathrm{g})$, neomycin $(30 \mu \mathrm{g})$, bacitracin (10 U), kanamycin (30 $\mu \mathrm{g})$, streptomycin (10 $\mu \mathrm{g})$, penicillin $\mathrm{G}(10 \mathrm{U})$, tetracycline $(30 \mu \mathrm{g})$, and aureomycin $(30 \mu \mathrm{g})$.

The same technique was applied to the determination of susceptibility to the following miscellaneous inhibitors: vibriostatic pteridin $\mathrm{O} / 129(100$ $\mu \mathrm{g}), \mathrm{KCN}(75 \mu \mathrm{g})$, lysozyme $(50 \mu \mathrm{g})$, acriflavin (200 $\mu \mathrm{g})$, urethane $(50 \mu \mathrm{g})$, and 8-hydroxyquinoline (100 $\mu \mathrm{g})$.

\section{RESULTS}

Cell shape, Gram stain, and motility. The cells of the three strains were gram-negative, straight or slightly curved rods with rounded ends; they usually occurred singly although older cultures showed filamentous or chained forms. After $24 \mathrm{~h}$, the cells appeared to be from 2.0 to $4.0 \mu \mathrm{m}$ in length and 0.8 to $1.5 \mu \mathrm{m}$ in diameter. They were motile, except for the filamentous forms, by means of a single polar flagellum (Fig. 1). Motility decreased quickly after 3 or 4 days, both in liquid and solid media.

Culture characteristics. The three strains were strictly aerobic: none could grow in an oxygen-free atmosphere.

On MA, the colonies were small $(0.5 \mathrm{~mm}$ in diameter), bright, and pinkish white after $24 \mathrm{~h}$ at $23^{\circ} \mathrm{C}$. The centers then turned to red, sometimes to blue. After 4 days, the colonies were circular (5 to $6 \mathrm{~mm}$ in diameter), convex, and bright, with a smooth surface, vermilion in colour, with a narrow pink edge and a deep red, sometimes bluish, center, and two or three deep red concentric rings, giving the appearance of a target. Variants were also present that were uniformly light pink. Colonies of strain 198 were more markedly blue coloured in young cultures. Strain 18 produced an orange-brown diffusible pigment. The addition of starch to the medium $(5 \%, \mathrm{wt} / \mathrm{vol})$ produced an increase in the pigmentation of the colonies, which became a solid deep red. The colonies were surrounded by an opalescent ring where starch had been hydrolysed.

On blood MA, all strains produced large ( 6 to $7 \mathrm{~mm}$ in diameter), bright (strains 18 and 173) or glossy (strain 198), rather mucoid, and uniformly deep red, almost black, colonies, each surrounded by a ring of complete hydrolysis. The colonies produced a brown, diffusible pigment and an odour of hydrogen cyanide.

After 4 days on TSA and NA, strains 18 and 198 gave rise to smaller colonies (2 to $3 \mathrm{~mm}$ in diameter), which were light beige in colour. The colonies of strain 173 were pale pink with a brilliant pink center. On these media, strain 18 produced an orange-brown, diffusible pigment, 


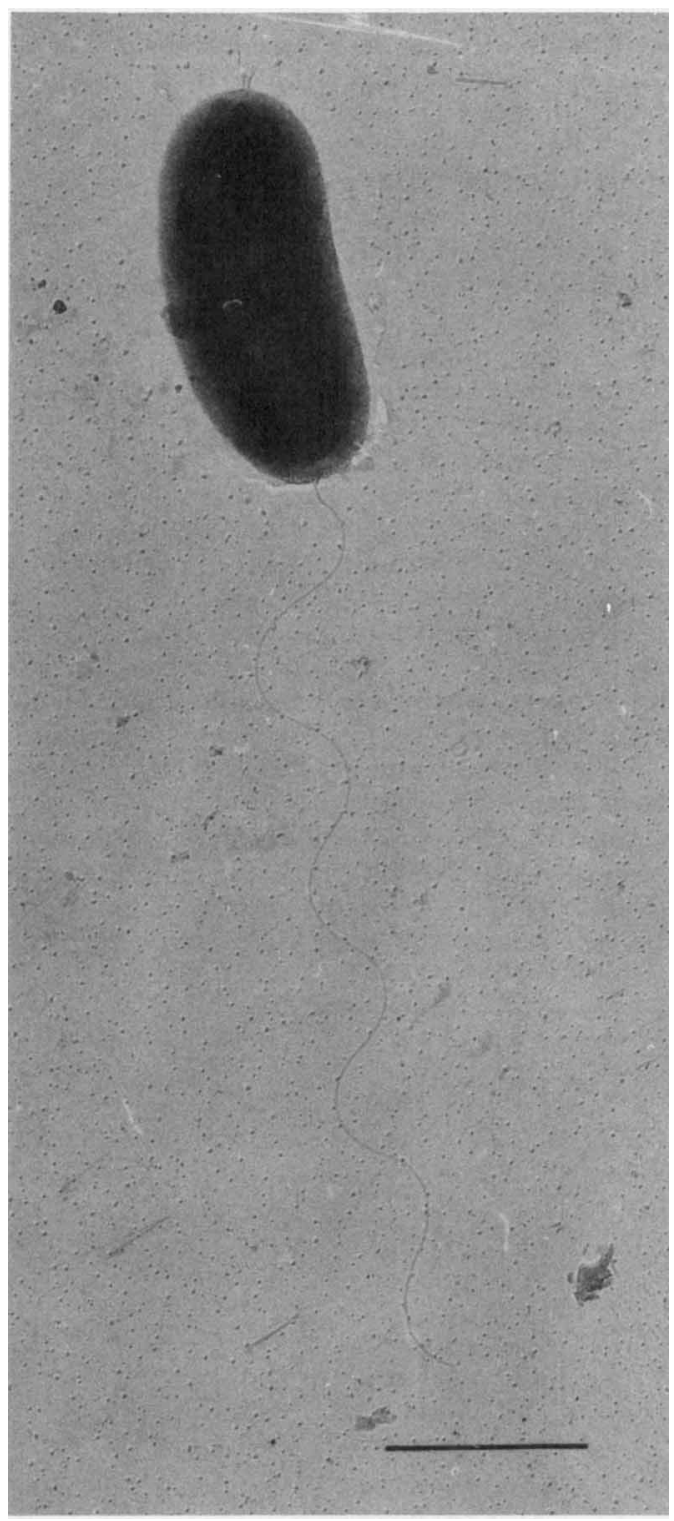

Fig. 1. Electron micrograph of strain 18 ( $=$ NCMB 1890). Bar represents $1 \mu \mathrm{m}$.

more abundant than the pigment produced on MA.

On King medium B, all strains produced a still more abundant diffusible pigment which turned from orange to brown. The colonies, which ranged in colour from pink to orange, were small ( $2 \mathrm{~mm}$ in diameter).

After 4 days in $\mathrm{MB}$, at $23^{\circ} \mathrm{C}$, the bacteria appeared to grow in the top centimeter only, forming a thin, fairly discontinuous pellicle that changed from pink to red and a red ring that adhered to the glass. The turbid area was a rather pale yellow-ochre, except with strain 18 . There was a very slight pale pink sediment.

In the gelatin (Difco) stab, liquefaction took place rapidly (24 to $48 \mathrm{~h}$ ) around the stab over an area 1.0 to $1.5 \mathrm{~cm}$ in diameter. The hydrolysate was a clear, colorless fluid.

Growth at different $\mathrm{pH}$ values, temperatures, and salinities, and requirement for sodium. All three strains were able to grow between 10 and $37^{\circ} \mathrm{C}$ and tolerated a variation of $\mathrm{pH}$ from 6 to 10 . They could not grow in artificial seawater medium with a salinity less than $7 \%$. Growth was poor around $10 \%$, normal up to $70 \%$, slow at $85 \%$ and absent at $112 \%$ salinity.

The study of $\mathrm{Na}^{+}$requirements showed that the inability of the strains to grow in freshwater media is mainly due to the absence of this ion. The $\mathrm{Na}^{+}$concentration for optimum growth was about $0.4 \mathrm{M}$, and between 0.4 and 1.0 $\mathrm{M}$ there were slight decreases in growth response (Fig. 2).

Antibiotic production. The properties of the antibiotic produced by strain 18 were described previously (7). Antibiotic production was greatest on MA, and generally it was better on seawater media than on media lacking seawater, when the cultures were incubated at a temperature not exceeding $35^{\circ} \mathrm{C}$. Antibiotic production was very low on blood MA; in this case, the lack of activity might be due to the presence of cata-

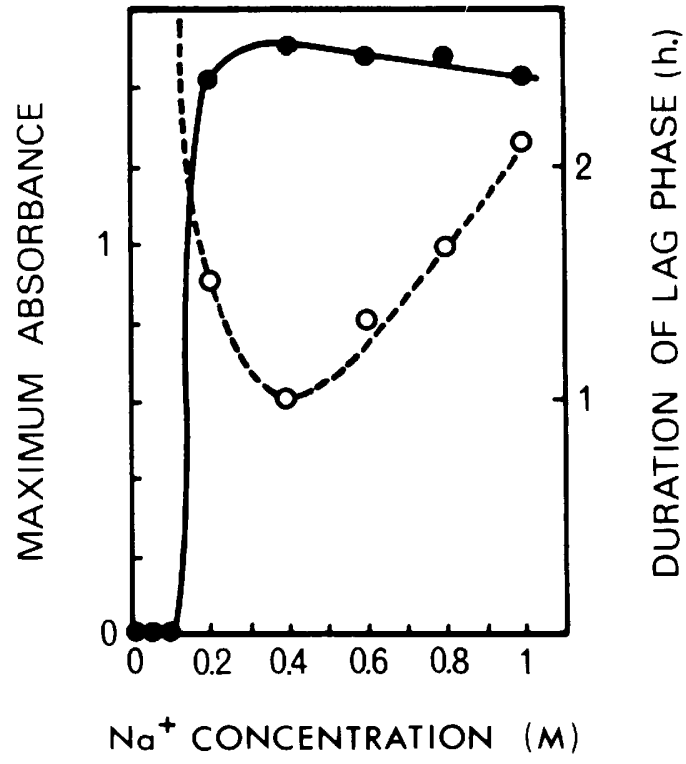

FIG. 2. Sodium requirement of strain 18 ( $=$ NCMB 1890) studied by means of a biophotometre; incubation in stirred medium at $23^{\circ} \mathrm{C}$. Symbols: ๑, maximum absorbance of cultures; $\bigcirc$, duration of lag phase. 
lase in the medium (5). Antibiotic production was also low on NA and TSA containing salt.

Pigment production. All three strains produced a red pigment on seawater media. This synthesis was enhanced by the addition of starch.

The absorption spectra of ethanolic extracts of the pigments (Fig. 3) showed marked similarities with that of the same extract from $S$. marcescens, with a maximum absorption peak at $540 \mathrm{~nm}$ in acid medium, drifting to $485 \mathrm{~nm}$ in alkaline medium (i.e., a change in colour from purple to orange-yellow). The pigment produced by the red marine strains thus appears to resemble prodigiosin. This pigment is, in fact, made up of several fractions which can be separated chromatographically (14). High-pressure liquid chromatographs of the chloroformmethanol extracts (Fig. 4) showed a relative heterogeneity in the compositions of the pigments produced by the marine strains as well . as some similarities and differences between the "prodigiosin" of $S$. marcescens and these pigments. Thus, the four pigments seemed to be related but not identical.

Range of organic compounds utilized. Of the 33 organic substrates tested, only glucose, trehalose, mannose, and starch were utilized as sole sources of carbon. In particular, the strains were unable to use the intermediary metabolites of the tricarboxylic acid cycle; furthermore, they could not use ortho-hydroxybenzoate. Sugars were utilized only oxidatively.

PHB accumulation. The three strains were unable to utilize DL- $\beta$-hydroxybutyrate and did not accumulate its polymer.

Enzyme production. The three strains produced an oxidase, a cytochrome oxidase, and a peroxidase that were very active. In contrast, their catalase activity was weak and irregular, especially that of strain 173 .

These strains also produced a tryptophan deaminase, an amylase, several proteases that provide for casein and gelatin hydrolysis, a lecithinase, a Tween-esterase, a tributyrate lipase, and a deoxyribonuclease. They hydrolysed esculin. Only strains 18 and 173 decarboxylated lysin. None of them produced arginine dihydrolase, phenylalanine deaminase, ornithine decarboxylase, urease, or tryptophanase.

None of the strains hydrolysed chitin or reduced nitrates to nitrites.

The results of the tests performed to determine the utilisation of synthetic substrates are given in Table 1. These demonstrated that, like the type strain of $A$. macleodii, strain 107, the

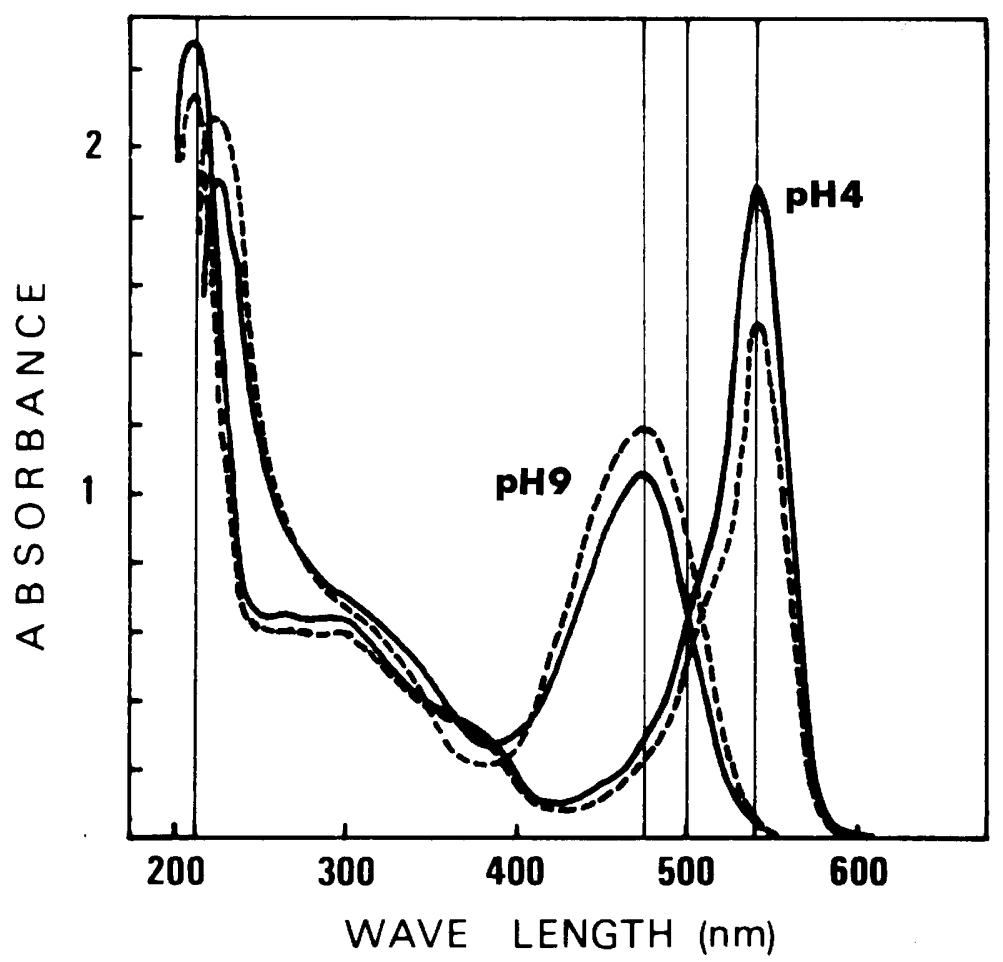

Fig. 3. Absorption spectra of crude ethanolic extracts of the pigments produced by strain 18 (solid lines) and S. marcescens (dashed lines) in acid ( $\mathrm{pH} 4$ ) and in alkaline ( $\mathrm{pH} 9$ ) media. 


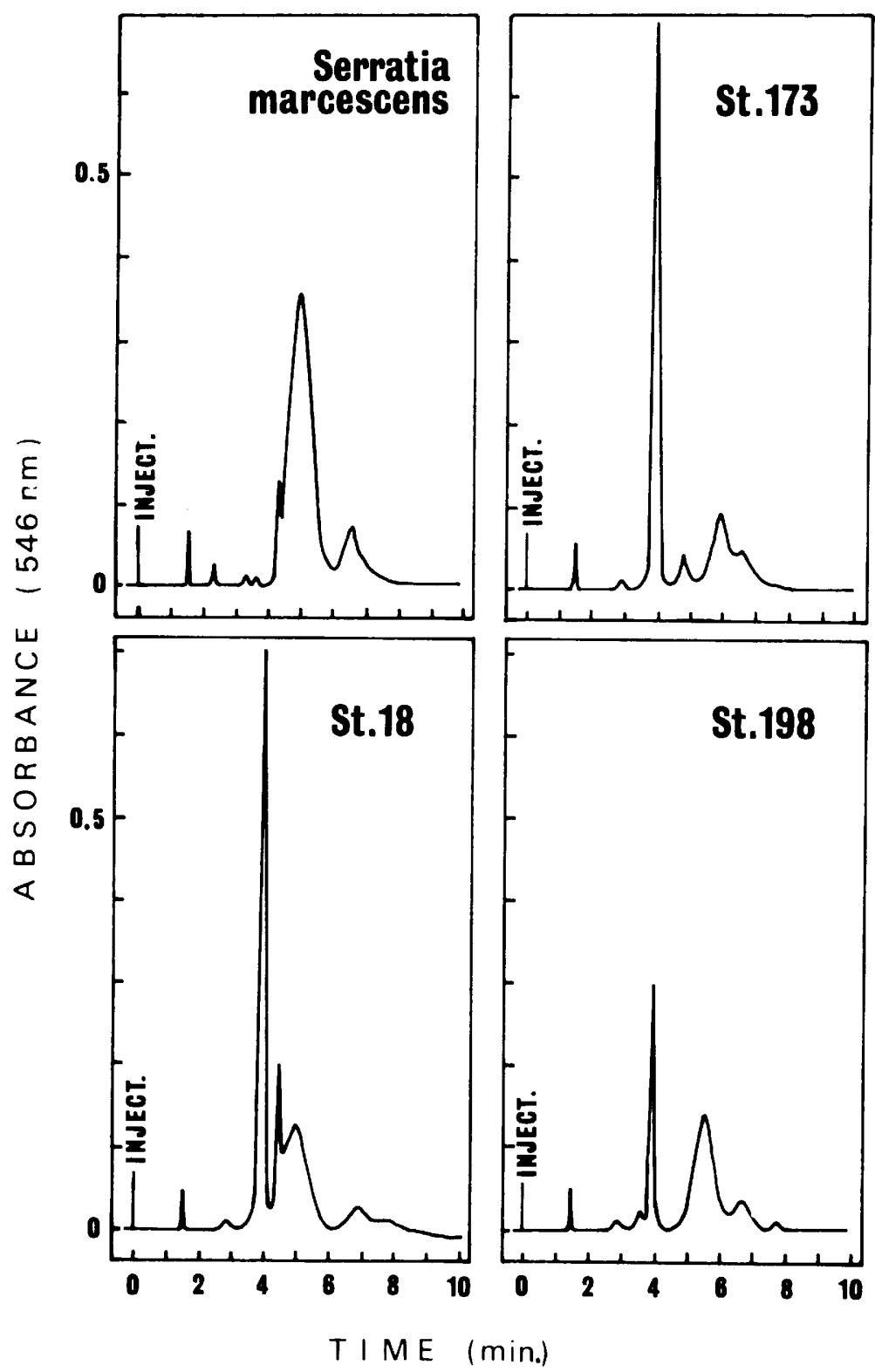

Fig. 4. Fractionation of the chloroform-methanol extracts of red-pigmented marine strains $(18,173$, and 198 ) and $S$. marcescens by high-pressure liquid chromatography. Prodigiosin and the red pigments from the marine strains appear to be composite, some components of prodigiosin (retention times, 5.05 and $6.45 \mathrm{~min}$ ) being present in the marine strains.

marine strains investigated in this study had a high phosphatase activity and produced some aminopeptidases. However, unlike $A$. macleodii 107 , the marine strains produced $\beta$-glucosaminidase.

Susceptibility to inhibitors. Antibiotics. All three strains were susceptible to erythromycin, spiramycin, polymyxin, vancomycin, chloramphenicol, thiophenicol, rifamycin, colistin, neo- mycin, novobiocin, and oleandomycin. They were faintly inhibited by streptomycin, tetracycline, aureomycin, staphylomycin, and kanamycin and were totally resistant to penicillin G. Bacitracin was active only against strains 18 and 173. A. macleodii 107 exhibited the same susceptibility spectrum as the marine strains, except that it was resistant to bacitracin and thiophenicol. 
TABLE 1. Enzyme activities of the three redpigmented marine strains and of the type strain of $A$. macleodii

\begin{tabular}{|c|c|c|c|c|}
\hline \multirow[b]{2}{*}{ Enzymes } & \multicolumn{4}{|c|}{ Enzyme activity ${ }^{a}$} \\
\hline & $\begin{array}{l}\text { Strain } \\
18\end{array}$ & $\begin{array}{l}\text { Strain } \\
173\end{array}$ & $\begin{array}{c}\text { Strain } \\
198\end{array}$ & $\begin{array}{l}\text { A. ma- } \\
\text { cleodii }\end{array}$ \\
\hline Alkaline phosphatase & +++ & +++ & +++ & +++ \\
\hline Acid phosphatase & +++ & +++ & +++ & +++ \\
\hline Esterase $\left(\mathrm{C}_{4}\right)$ & - & - & - & - \\
\hline Esterase lipase $\left(C_{8}\right)$ & ++ & ++ & ++ & ++ \\
\hline Lipase $\left(\mathrm{C}_{14}\right)$ & + & + & - & - \\
\hline Leucine aminopeptidase & ++ & ++ & ++ & ++ \\
\hline Valine aminopeptidase & + & + & + & ++ \\
\hline Cystine aminopeptidase & - & - & + & - \\
\hline $\begin{array}{l}\text { Trypsin (or related en- } \\
\text { zyme) }\end{array}$ & +++ & +++ & +++ & +++ \\
\hline $\begin{array}{l}\text { Chymotrypsin (or related } \\
\text { enzyme) }\end{array}$ & + & + & + & - \\
\hline$\alpha$-Galactosidase & - & - & - & - \\
\hline$\beta$-Galactosidase & - & - & - & - \\
\hline$\beta$-Glucuronidase & - & - & - & - \\
\hline$\alpha$-Gilucosidase & - & - & - & - \\
\hline$\beta$-Glucosidase & - & - & - & - \\
\hline$\beta$-Glucosaminidase & ++ & $+t$ & ++ & - \\
\hline$\alpha$-Mannosidase & - & - & - & - \\
\hline$\alpha$-Fucosidase & - & - & - & - \\
\hline Phosphoamidase & ++ & ++ & ++ & + \\
\hline
\end{tabular}

${ }^{a}+$, Positive reaction (proportional to the number of crosses); - , negative reaction.

Vibriostatic pteridin $0 / 129$. Vibriostatic pteridin $\mathrm{O} / 129$ proved inactive toward all the strains. The results are not fully reliable, however, because the test was carried out in a saline medium (10).

Respiratory effectors. All three strains were inhibited by cyanide, acriflavin, and 8-hydroxyquinolin; they were resistant to lysozyme and urethane.

Miscellaneous reactions. None of the strains produced $\mathrm{H}_{2} \mathrm{~S}$ or gave a positive methyl red or Voges-Proskauer reaction. Strains 173 and 198 partly reduced methylene blue in the depth of MB. They showed a marked "catalase effect" which, as in the case of A. luteoviolaceus, is probably related to the mode of action of the self-inhibiting antibiotic they produce.

DNA base composition. The guanine plus cytosine $(\mathrm{G}+\mathrm{C})$ contents of the deoxyribonucleic acids (DNAs) of strains 18, 173, and 198 were $47.1,47.3$, and $46.9 \mathrm{~mol} \%$, respectively.

\section{DISCUSSION}

The phenotypic characters of the three marine strains studied permit these strains to be included in Shewan's group IV of the genus Pseudomonas (13). However, their DNA contains a low percentage of $\mathrm{G}+\mathrm{C}$ compared with that of the pseudomonads and, therefore, they are assigned to the genus Alteromonas which, according to Baumann et al. (2) and Reichelt and Baumann (11), contains the pseudomonads having low $\mathrm{G}+\mathrm{C}$ contents in their DNAs.

The three strains investigated in this study have a number of characters in common with and a few differences between the alteromonads previously described (Table 2). When the data given by Reichelt and Baumann (12) for several heterotrophic marine bacteria are compared with the $\mathrm{Na}^{+}$requirements of the three isolates reported here, it is evident that the latter organisms are more sensitive to low $\mathrm{Na}^{+}$ concentrations than are the former, since the latter cannot grow in the presence of less than $0.1 \mathrm{M} \mathrm{Na}^{+}$. Thus, the strains described here seem similar to the strain 212 of group I-2 of Baumann, et al. (2).

The $\mathrm{G}+\mathrm{C}$ values of the three marine strains are close to those of $A$. vaga, $A$. communis, and A. macleodii. However, the marine strains are quite different phenotypically from A. vaga and $A$. communis. There are fewer differences between the marine strains and $A$. macleodii, but they may be significant. Thus, the red-pigmented marine strains consist of more or less curved rods, are unable to grow at $40^{\circ} \mathrm{C}$, have a reduced, irregular catalase activity and a strong glucosaminidase activity, are unable to utilize maltose, cellobiose, or glycerol as the sole source of carbon, and produce "prodigiosin" as well as a macromolecular, autotoxic antibiotic substance; such characteristics are not present in A. macleodii.

The morphological, physiological, and biochemical similarities of the three strains investigated make it possible to group them in a single species that is sufficiently different from other alteromonads to be considered a new species, for which we propose the name Alteromonas rubra (rub'ra. L. fem. adj. rubra red). Strain 18 (=NCMB 1890) is designated the type strain of this species.

Like A. luteoviolaceus, which produces violacein, a pigment already described as specific to terrestrial bacteria belonging to the genus Chromobacterium, A. rubra synthesizes a composite pigment similar to prodigiosin, which was previously found to occur only in serratias. The difference between $A$. rubra and the terrestrial or marine strains of the genus Serratia being obvious, it is no longer possible to regard prodigiosin production as unique to Serratia.

All of the strains belonging to the species $A$. rubra that have been isolated and investigated so far show a high antibiotic activity toward many terrestrial and marine bacteria. The polyvalent anions responsible for antibiotic activity are effective in modifying respiratory processes; it is possible, therefore, that in these 
TABLE 2. Some distinguishing characters of Alteromonas species and three red-pigmented marine strains

\begin{tabular}{|c|c|c|c|c|c|c|}
\hline \multirow[t]{2}{*}{ Character } & $\begin{array}{c}\text { A. } \text { commu- }^{n i s^{a}} \\
\text { n }\end{array}$ & A. vaga $a^{a}$ & $\begin{array}{l}\text { A. macleo- } \\
d i i^{a}\end{array}$ & $\begin{array}{l}\text { A. halo- } \\
\text { planktis }^{b}\end{array}$ & $\begin{array}{l}\text { A. luteovio- } \\
\text { laceus }^{c}\end{array}$ & $\begin{array}{l}\text { Red-pig- } \\
\text { mented ma- } \\
\text { rine strains }\end{array}$ \\
\hline & $33^{d}$ & 17 & 21 & 17 & 16 & 3 \\
\hline Straight rods & $-e$ & + & + & + & + & +- \\
\hline Oxidase & + & - & + & + & + & + \\
\hline Catalase & $\mathrm{ND}^{f}$ & $\mathrm{ND}$ & + & ND & - & $(+)$ \\
\hline Amylase & - & - & $(19)^{g}$ & (1) & (15) & + \\
\hline Gelatinase & - & - & $(20)$ & + & + & + \\
\hline Lipase & - & - & + & + & + & + \\
\hline Chitinase & - & - & - & (14) & - & - \\
\hline D-Glucose & + & + & + & + & (9) & + \\
\hline D-Mannose & (29) & + & - & (15) & - & + \\
\hline Maltose & (26) & (6) & + & + & + & - \\
\hline Trehalose & (6) & (3) & (19) & (13) & + & + \\
\hline Cellobiose & - & (14) & + & - & - & - \\
\hline Succinate & + & + & - & + & ND & - \\
\hline$\alpha$-Ketoglutarate & + & + & - & - & ND & - \\
\hline Erythritol & - & + & - & - & ND & - \\
\hline Glycerol & + & + & + & - & - & - \\
\hline Ring cleavage & + & + & - & - & ND & - \\
\hline$m-\mathrm{OH}$ benzoate & + & + & - & - & ND & - \\
\hline Violacein & - & - & - & - & (14) & - \\
\hline Prodigiosin & - & - & - & - & - & + \\
\hline Synthesis of antibiotic & ND & ND & - & ND & + & + \\
\hline Growth at $40^{\circ} \mathrm{C}$ & + & - & (15) & - & - & - \\
\hline $\mathrm{Mol} \% \mathrm{G}+\mathrm{C}$ & 47 & 48 & 46 & 43 & 42 & 47 \\
\hline
\end{tabular}

${ }^{a}$ Data from Baumann et al. (2).

${ }^{b}$ Data from Reichelt and Baumann (11).

"Data from Gauthier (6).

"Number of strains examined.

"Symbols: +, all strains positive; -, all strains negative; (+), slight positive reaction; +-, variable.

${ }^{f}$ ND, Not determined.

${ }^{g}$ Figures in parentheses are numbers of positive strains.

bacteria the respiratory chain contains some peculiarities that would permit their differentiation from marine pseudomonads.

\section{ACKNOWLEDGMENTS}

We wish to thank P. Baumann for his advice during the course of this study and for the culture of Alteromonas macleodii 107 that was kindly provided.

We also thank H. Leclerc (Unité de Recherches INSERM U.146, Lille, France) for permission to use the electron microscope of the Service de Microscopie Electronique de l'Institut Pasteur (Lille), and J. M. Delattre and G. Torpier, who performed the electron microscopy.

We are also grateful to $R$. Clément for his technical cooperation in the performance of the bacteriological tests and to G. Flatau, N. Zsürger and E. Dutripon for their advice during the chromatographic analyses.

\section{REPRINT REQUESTS}

Address reprint requests to: Dr. M. J. Gauthier, Centre d'Etudes et de Recherches de Biologie et d'Océanographie Médicale-I.N.S.E.R.M. U40, 1, Avenue Jean Lorrain, 06300 , Nice, France.

\section{LITERATURE CITED}

1. Baumann, P., L. Baumann, and M. Mandel. 1971. Taxonomy of marine bacteria: the genus Beneckea. J. Bacteriol. 107:268-294.

2. Baumann, L., P. Baumann, M. Mandel, and R. D.
Allen. 1972. Taxonomy of marine eubacteria. J. Bacteriol. 110:402-429.

3. Brisou, J. 1971. Techniques d'enzymologie bactérienne. Masson \& Cie, Paris.

4. Chabbert, Y. A. 1963. L'antibiogramme. Collection techniques de base, Ed. Tourelle, St. Mandé.

5. Gauthier, M. J. 1972. Antagonismes et synergies dans l'antibiose chez certaines bactéries marines. Rôle de certains enzymes respiratoires dans ces phénomènes. Rev. Int. Océanogr. Méd. 26:65-84.

6. Gauthier, M. J. 1976. Morphological, physiological and biochemical characteristics of some violet pigmented bacteria isolated from seawater. Can. J. Microbiol. 22:138-149.

7. Gauthier, M. J. 1976. Modification of bacterial respiration by a polyanionic antibiotic produced by a marine Alteromonas. Antimicrob. Agents Chemother. 9:361366.

8. Gauthier, M. J., J. M. Shewan, D. M. Gibson, and J. V. Lee. 1975. Taxonomic position and seasonal variations in marine neritic environment of some gramnegative antibiotic-producing bacteria. J. Gen. Microbiol. 87:211-218.

9. Lyman, J., and R. H. Fleming. 1940. Composition of seawater. J. Mar. Res. 3:134-146.

10. Merkel, J. R. 1972. Influence of salts on the vibriostatic action of 2,4-diamino-6,7-diisopropyl pteridine. Arch. Microbiol. 81:379-382.

11. Reichelt, J. L., and P. Baumann. 1973. Change of the name Alteromonas marinopraesens (ZoBell and Upham) Baumann et al. to Alteromonas haloplanktis 
(ZoBell and Upham) comb. nov. and assignment of strain ATCC 23821 (Pseudomonas enalia) and strain C-A1 of DeVoe and Oginsky to this species. Int. J. Syst. Bacteriol. 23:438-441.

12. Reichelt, J. L., and P. Baumann. 1974. Effect of sodium chloride on growth of heterotrophic marine bacteria. Arch. Microbiol. 97:329-345.

13. Shewan, J. M. 1963. The differentiation of certain gen- era of gram-negative bacteria frequently encountered in marine environments, p. 499-521. In C. H. Oppenheimer (ed.), Symposium on marine microbiology. Charles C Thomas, Springfield, Ill.

14. Williams R. P., J. A. Green, and D. A. Rappoport. 1956. Studies on pigmentation of Serratia marcescens. I. Spectral and paper chromatographic properties of prodigiosin. J. Bacteriol. 71:115-120. 